\title{
Themes in Southern African linguistics
}

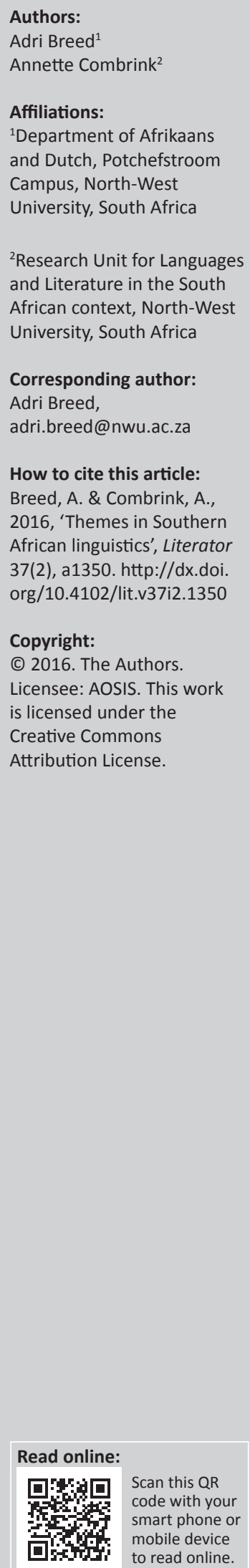

This special issue of Literator, Themes in Southern African linguistics, complements the 2015 Linguistics Society of South Africa/Southern African Applied Linguistics Association/ South African Association for Language Teachers (LSSA/SAALA/SAALT) joint annual conference. This issue contains articles from the fields represented by all three linguistics organisations: LSSA, SAALA and SAALT.

Two articles in this edition, namely, 'Designing a digital pedagogical pattern for improving foreign language learners' oral proficiency' by Carina Grobler and Tom Smits and 'Blended learning in a first-year language class: Evaluating the acceptance of an interactive learning environment' by Jako Olivier, focus on the use of digital teaching methods in teaching language to university students.

Three language practice articles appear in this edition. Amanda Lourens' article, 'Die gebruik van opmerkings as ' $n$ strategie tydens die verantwoordbare redigering van akademiese tekste' [The use of comments as a strategy in the accountable editing of academic texts], provides guidelines to using a process approach when editing academic texts. Amanda Nokele and Koliswa Moropa's article, 'Indlela or uhambo? Translator style in Mandela's autobiography', provides a methodological framework for research regarding the individual style of literary translators, especially those working in African languages. Ketiwe Ndlovu's 'Using ParaConc to extract bilingual terminology from parallel corpora: A case of English and Ndebele' focuses on the development of African languages into languages of science and technology.

Ian Sieborger and Courtney de Barros's article, entitled 'Sentential negation in South African Sign Language: A case study', demonstrates how hands and other body parts are used to express sentence negation in South African Sign Language by using a principles and parameters approach and Government and Binding Theory.

In Maryka van Zyl and Yolande Botha's article, entitled 'Stylometry and characterisation in The Big Bang Theory', corpus linguistics methods are used to determine which linguistic choices are made by screenplay writers to ensure that a specific character's dialogue in the television series The Big Bang Theory, namely, Sheldon Cooper, is distinctive from the other characters in the series.

In the article, 'Inference generation and text comprehension in bilingual children: A case study', Agness Hara and Heike Tappe investigate the processes used by 10-12-year-old bilingual Malawian children to make assumptions after listening to stories in their first language (L1: Chichewa) as compared to stories in their second language (L2: English) or in animated films without any verbal content.

Finally, the South African language variety is investigated in two articles: Anna Maritz's 'Black Afrikaans: An alternative use' and Thabo Ditsele and Ellen Hurst's 'Travelling terms and local innovations: The tsotsitaal of the North West province, South Africa'. The first article examines the alternative function of Black Afrikaans as realised when this variety is copied or imitated. The second article contains an analysis of the linguistic structures and lexical items of Tsotsi language as spoken in North West cities.

The articles that appear in this special issue are a reflection of the range and variety of linguistics research undertaken and presented annually by South African linguists at the joint conferences.

Note: Adri Breed and Annette Combrink were guest editors for Literator 37(2): Themes in Southern African linguistics. 